\title{
DNA Polymerase Delta Subunit 3
}

National Cancer Institute

\section{Source}

National Cancer Institute. DNA Polymerase Delta Subunit 3. NCI Thesaurus. Code C106229.

DNA polymerase delta subunit $3(466 \mathrm{aa}, \sim 51 \mathrm{kDa})$ is encoded by the human POLD3 gene. This protein plays a role in DNA replication. 